\title{
Effects of Financial Crises on Latin American Economies-Colombia Case and the SMEs
}

\author{
Jenny A. SEGURA And Victor J. SARMIENTO \\ Corporación Universitaria Minuto de Dios, Uniminuto, Bogotá, Colombia
}

Correspondence should be addressed to: Jenny A. SEGURA; jseguraosun@uniminuto.edu.co

Received date: 12 November 2019; Accepted date: 7 July 2020; Published date: $1^{\text {st }}$ September 2020

Copyright (C) 2020. Jenny A. SEGURA and Victor J. SARMIENTO. Distributed under Creative Commons Attribution 4.0 International CC-BY 4.0

\begin{abstract}
This article analyzes the most representative international financial crises in Colombia since 1990: the Asian crisis of 1997 and the Sub-Prime crisis of 2008 in the United States. Likewise, the impacts and their effects on national production in some Latin American countries are indicated. Finally, it is shown how financial literacy cushions the negative effects on small and medium-sized enterprises (SMEs), which are of vital importance in the economy for its contribution to GDP and the generation of formal jobs.
\end{abstract}

Keywords: Financial crisis; financial literacy; GDP; SMEs.

\section{Introduction}

Economies have periods of growth, expansion and boom, as well as periods of slowdown and crisis, which occur over time as part of what in economics are called business cycles, which depend on internal and external factors, political, social, natural and demographic (Samuelson, 1967). Among the main causes for which the economies of the countries, both emerging and developed, are affected and present falls in national production as measured by the Gross Domestic Product (GDP), it has to do with what happens to the financial system and its crises, which are expanding rapidly given the degree of globalization and openness not only of an economic and commercial type but also of a cultural and technological type (Larraín and Sachs 2002).
The functioning of financial markets has been of great importance in explaining the falls in real activity, since in the last 200 years approximately 300 financial crises have occurred, the most critical being that of 1930, also known as the "Great Depression" and that of 2008 or "Crisis subprime", (Machinea, 2009). This author also identifies the instability of the financial system as the main cause of financial crises.

In the development of this article, we present what happened in Asia at the end of the last century in Asian countries such as Malaysia, Korea, Indonesia, Thailand, among others, and that affected several countries, reaching as far as Latin America, including Colombia where they lived a very strong economic recession (Cepal, 1998). Likewise, the mortgage or subprime crisis that broke out in 2008 in the United States

Cite this Article as: Jenny A. SEGURA And Victor J. SARMIENTO (2020), "Effects of Financial Crises on Latin American Economies-Colombia Case and the SMEs", Journal of Economics Studies and Research, Vol. 2020 (2020), Article ID 808445, DOI: 10.5171/2020.808445 
is presented and expanded worldwide (Titelman, Pérez, and Pineda, 2009) and had strong impacts on the Colombian economy (Ocampo, 2009).

From the lessons left in the last 22 years, SMEs in Colombia and other Latin American countries should be able to make the best decisions in economic and financial matters, for which a certain degree of financial literacy and economic knowledge. In accordance with the above, it is desired to show what the effects of the said crises were at the macroeconomic level in Colombia and on the economic results of SMEs.

\section{Methodology}

This article is a literature review on what happened in the aforementioned financial crises, which had strong consequences on the dynamics of the Colombian economy and on that of other Latin American countries, in order to identify the factors that make these economies in the presence of these crises and what their effects are on small and medium-sized companies, which can use financial literacy as a tool to cushion the strong effects of these crises.

According to Guirao, Olmedo and Ferrer (2008), review articles "is a type of scientific article that without being original collects the most relevant information on a specific topic". In that order of ideas, first of all, inquiries are made about crises as part of a country's economic cycle, what is a crisis in the financial system and how it affects the general performance of a country or group of countries, that at a theoretical level, to At an empirical level, the causes, development and consequences of the two crises studied in this document are analyzed taking as a specific case what happened in Colombia.

As an additional analysis tool to the documentary review, it is presented through a table and a graph which were the effects of the said crises in other Latin American economies, where it can be seen that the impact was generalized given the high interconnection of the markets and economies globally.

This research shows how even in Colombia and in other Latin American countries there are shortcomings in financial literacy issues, at the level of the general population, but also in people who are in charge of the administration and finances of small and medium-sized companies. Given this limitation of knowledge in this important area, financial literacy is proposed as a tool for SMEs to face financial crises and sustain themselves in the market over time, since many of them are born, but in less than five years are already out of the market.

\section{Results}

Stylized facts of the financial crises of 1997 and 2008 and framework

In Latin America, the financial crises of Asia in 1997 and that of the United States in 2008 have been the most important in terms of their negative effect on the economies of Latin America, as shown in Figure and Table 1 , after these crises the annual variation in GDP reflects slowdowns and in some cases falls in this important indicator of economic activity: 

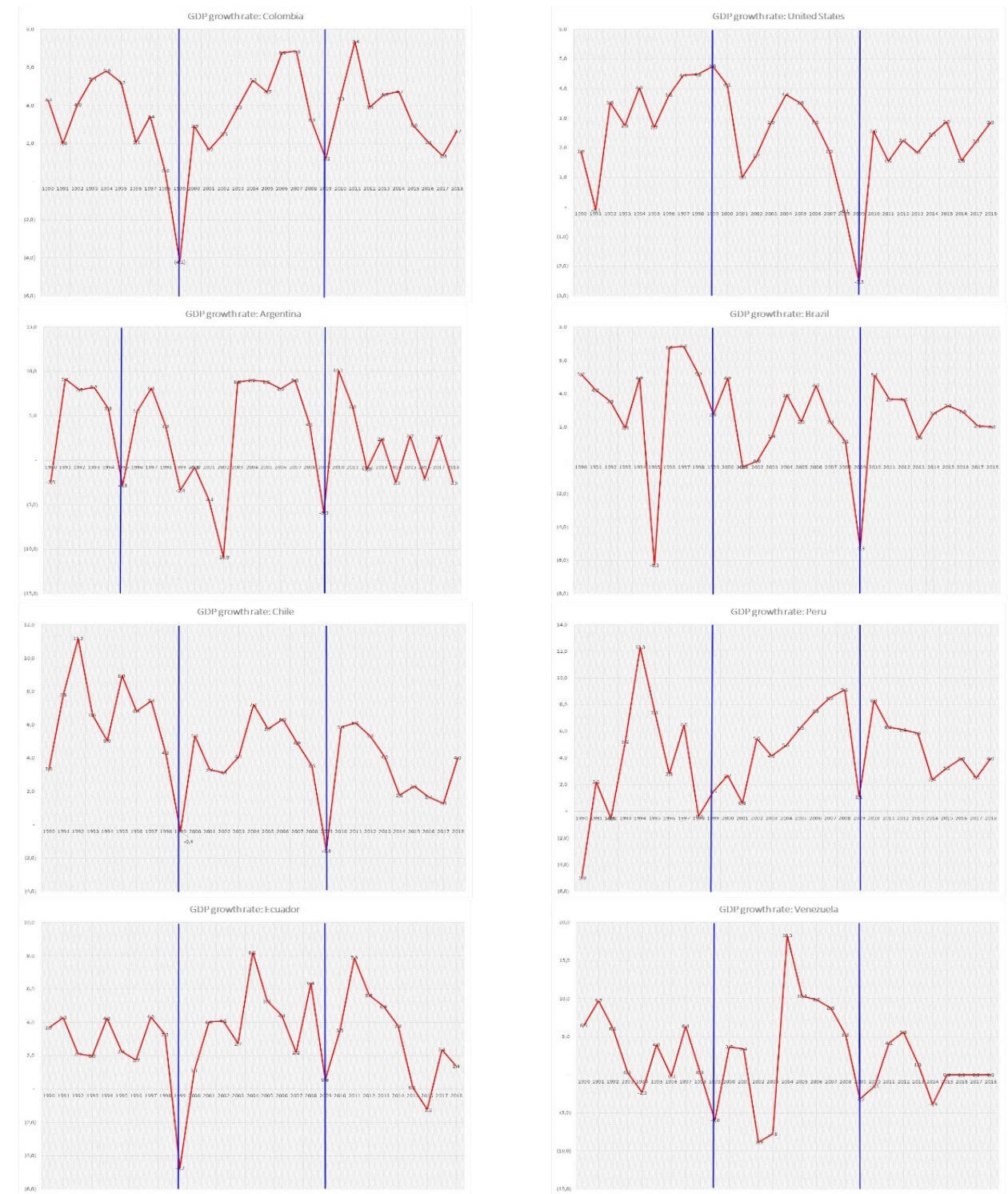

Fig. 1: Variation\% of real GDP by country, own elaboration with World Bank data 
Table 1: Annual\% change in real GDP, own elaboration with World Bank data

\begin{tabular}{|l|r|r|r|r|r|r|r|r|r|r|r|r|r|r|r|r|r|r|}
\hline Country & 1995 & 1996 & 1997 & 1998 & 1999 & 2000 & 2001 & 2002 & 2003 & 2004 & 2005 & 2006 & 2007 & 2008 & 2009 & 2010 & 2011 & 2012 \\
\hline Argentina & $(2,8)$ & 5,5 & 8,1 & 3,9 & $(3,4)$ & $(0,8)$ & $(4,4)$ & $(10,9)$ & 8,8 & 9,0 & 8,9 & 8,0 & 9,0 & 4,1 & $(5,9)$ & 10,1 & 6,0 & $(1,0)$ \\
\hline Brazil & 4,4 & 2,2 & 3,4 & 0,3 & 0,5 & 4,4 & 1,4 & 3,1 & 1,1 & 5,8 & 3,2 & 4,0 & 6,1 & 5,1 & $(0,1)$ & 7,5 & 4,0 & 1,9 \\
\hline Chile & 8,9 & 6,8 & 7,4 & 4,3 & $(0,4)$ & 5,3 & 3,3 & 3,1 & 4,1 & 7,2 & 5,7 & 6,3 & 4,9 & 3,5 & $(1,6)$ & 5,8 & 6,1 & 5,3 \\
\hline Colombia & 5,2 & 2,1 & 3,4 & 0,6 & $(4,2)$ & 2,9 & 1,7 & 2,5 & 3,9 & 5,3 & 4,7 & 6,8 & 6,8 & 3,3 & 1,2 & 4,3 & 7,4 & 3,9 \\
\hline Ecuador & 2,3 & 1,7 & 4,3 & 3,3 & $(4,7)$ & 1,1 & 4,0 & 4,1 & 2,7 & 8,2 & 5,3 & 4,4 & 2,2 & 6,4 & 0,6 & 3,5 & 7,9 & 5,6 \\
\hline Mexico & $(6,3)$ & 6,8 & 6,8 & 5,2 & 2,8 & 4,9 & $(0,4)$ & $(0,0)$ & 1,4 & 3,9 & 2,3 & 4,5 & 2,3 & 1,1 & $(5,3)$ & 5,1 & 3,7 & 3,6 \\
\hline Peru & 7,4 & 2,8 & 6,5 & $(0,4)$ & 1,5 & 2,7 & 0,6 & 5,5 & 4,2 & 5,0 & 6,3 & 7,5 & 8,5 & 9,1 & 1,1 & 8,3 & 6,3 & 6,1 \\
\hline Paraguay & 6,8 & 1,6 & 4,2 & 0,1 & $(1,4)$ & $(2,3)$ & $(0,8)$ & $(0,0)$ & 4,3 & 4,1 & 2,1 & 4,8 & 5,4 & 6,4 & $(0,3)$ & 11,1 & 4,2 & $(0,5)$ \\
\hline Uruguay & $(1,4)$ & 5,6 & 8,5 & 4,5 & $(1,9)$ & $(1,9)$ & $(3,8)$ & $(7,7)$ & 0,8 & 5,0 & 7,5 & 4,1 & 6,5 & 7,2 & 4,2 & 7,8 & 5,2 & 3,5 \\
\hline United States & 2,7 & 3,8 & 4,4 & 4,5 & 4,8 & 4,1 & 1,0 & 1,7 & 2,9 & 3,8 & 3,5 & 2,9 & 1,9 & $(0,1)$ & $(2,5)$ & 2,6 & 1,6 & 2,2 \\
\hline Venezuela, RB & 4,0 & $(0,2)$ & 6,4 & 0,3 & $(6,0)$ & 3,7 & 3,4 & $(8,9)$ & $(7,8)$ & 18,3 & 10,3 & 9,9 & 8,8 & 5,3 & $(3,2)$ & $(1,5)$ & 4,2 & 5,6 \\
\hline
\end{tabular}

Analyzing the data of the percentage growth of the GDP for the chosen countries, it can be inferred that the United States always had growth, except when the real estate bubble burst in 2008 where the GDP fell $0.1 \%$ and $2.5 \%$ in 2008 and 2009 respectively, a phenomenon that was not observed in other years of the study period contemplated here. When observing the figures, it is also evident that countries such as Argentina, Paraguay, Uruguay and Venezuela, present shorter cycles where the fall in production is more frequent taking into account their particular economic, commercial and political structure, however all of them also coincide in to have a phase of economic recession after the crisis of the Asian countries and the real estate crisis except Uruguay, which by the end of the 2000s came with high economic dynamics and did not suffer significant impacts on its economy.

In the face of the crisis in the Asian countries, Brazil and Mexico presented a slowdown in economic growth, but no drop in GDP, contrary to the great impact of the 2008 mortgage crisis, since their production fell by $0.1 \%$ and $5.3 \%$ respectively, the great impact in Mexico given its proximity to the country where the crisis was born. In the case of Chile, in both crises its economic growth was affected, since for 1999 its economy decreased by $0.04 \%$ and in 2009 by $1.6 \%$. Ecuador, like Colombia, presented a drop in production with the Asian crisis of
$4.7 \%$ and a slowdown in productive activity after the collapse of the mortgage and financial market in the United States, in 2009 its growth was $0.6 \%$, showing a slowed economy.

In Peru, the impact of the Asian crisis came in 98 and not in 99 since for that year GDP fell by 0.4 , this result was also due to internal factors concerning mining and the phenomenon of children (Erdmann, Schulz, Richter and Rodríguez, 2008). For 2009, the year in which the subprime crisis hit most Latin American countries, production growth reached a level of $1.1 \%$, showing signs of a slowdown in the Inca economy.

It can be concluded that the international financial crises of 97 and 2008 had a heterogeneous impact on countries in Latin America, since in some there were drops in production and in others not, however, the negative change in dynamics was evidence in almost all.

\section{Asian crisis and 2008 subprime crisis}

The Asian crisis originated from "... The exhaustion of the Asian Miracle and the problems of moral hazard", the first refers to the extraordinary economic growth of these nations decades ago, and the second to the opportunistic behavior of financial entities which acted in a manner that their benefits were increasing while the interests of the users of the said financial services 
were left behind (Clavijo, 2000). Esquivel and Larraín (1999) maintain that this financial-exchange crisis that occurred in Asian countries spread to Latin America, affecting the purchasing power of these countries

Regarding the crisis of 2008, Ferguson (2010) affirms that this crisis was conceived from the end of the 20th century, more specifically from the 1970s, when little by little the legislative power of this country began to deregulate the financial system and the transactions led to out on this. All this led to financial institutions making a series of risky investments that made savers lose their investments. At that time, loans were affordable to the entire public, especially mortgages that financed up to $99 \%$ of the nominal value of housing, with which house prices tripled, creating a bubble that, after the crisis, burst and left thousands of homeless Americans.

The interconnection of institutions that offer financial services caused this crisis to spread rapidly and widely throughout the world, partly because of the so-called "financial innovation" as cited by Uribe (2011). Belda (2008) points out that the failure to pay these mortgages in the summer of 2007 was what triggered the crisis. This mortgage market underwent changes regarding its regulation in the nineties, with which there was a decrease in the supervision of the said loans and gave rise to moral hazard. Something that also favored the increase in subprime loans was financial innovations when mortgage and commercial banks merged, the latter took the opportunity to expand with the benefit of not being subject to rigorous surveillance.

The undervaluation of risk, issued by risk rating agencies, played a role in this crisis, since they gave a rating of AAA to some risky investments. In the end, these rating agencies justified their opinion as an opinion that did not involve a numerical and qualitative methodology of rigor. The crisis erupted and several financial entities went bankrupt, including Lehman Brothers and
Merril Lynch, and the Federal Reserve had to intervene by injecting millions of dollars into the financial system, so that its negative impacts would not be as dire as those of the Great Depression of 1929 Ferguson (2010).

Machinea (2009) points out that the instability of the financial system was the main cause of this financial crisis and that three factors influenced its great magnitude: firstly, the large size of the international financial system, which according to this author exceeds the GDP of developed countries, secondly the interconnection and globalization of financial institutions worldwide and lastly the penumbra regarding the information that financial institutions manage in the midst of their operation that knows no limits regarding their earnings and the product portfolio it offers. Chor and Manova (2012) point out that those companies with external sources of financing were seriously affected at the time of the crisis, since that moment they did not have financing.

Palomo and Sanchís (2010) show that even old-age pensions were affected since their profitability decreased and their volume also fell as a consequence of the increase in unemployment and informality and the evasion of the payment of this social contribution, as a consequence of the fall in world GDP growth. Zurdo and Palacio (2010) find that at the corporate level, many firms to avoid bankruptcies are restructured or merged with others, which can lead to the dismissal of employees and thus improve financial ratios. Titelman, Pérez, and Pineda (2009) indicate that the effects of this crisis were generalized, profound and long-lasting, and from one country to another they depended on the degree of openness to international trade and the global financial market, macroeconomic and general conditions, and policies carried out by the economic authority. 


\section{Colombia case}

In Colombia, the first crisis began to slow down the growth of the economy and the worst moment was experienced in 1999 when production fell by $4.2 \%$, the lowest in many years. This Asian financial crisis began in 1997 and spread to many countries in the world, including Colombia. Johnson, Boone, Breach and Friedman (2000) found that the Asian crisis of 1997 and 1998 was mainly due to macroeconomic reasons and the way the financial market worked at that time and, citing Krugman, he says that it was a consequence of the formation of bubbles in the price of assets. They also maintain that in this crisis there was loss of confidence on the part of national and foreign investors from emerging countries, which aggravated the problem since there was a massive outflow of capital from these nations.

According to Uribe (2011), the conditions for this economic crisis have been in place since the early nineties where there was also a financial opening that caused a decrease in domestic savings, high indebtedness, both private and public. By the time the impacts of this Asian crisis arrived in Colombia, mortgage credit was no longer a State monopoly and instead other entities that also granted this type of credit had entered the market, which were now of the "subprime" type, so that this market was exposed to credit and liquidity risk.

In addition to the $-4.2 \%$ drop in GDP, there was an increase in unemployment, which was close to $19 \%$. In the face of this crisis, the economic authorities of Colombia requested financing from the Multilateral Bank, the World Bank and the International Monetary Fund, according to Clavijo (2000), which cushioned the negative effects of the crisis, along with the help that it received at that time the country of the so-called "Plan Colombia", which sought to eradicate illicit crops, among other things, but which brought with it serious problems such as the violation of human rights (Chomsky, 2000).
After the recession of 99 , the Colombian economy had a recovery and even a high growth of $6.8 \%$ for the years of 2006 and 2007, especially marked by high aggregate demand. Already in 2008, given this situation and with great inflationary pressure, the Banco de la República began to raise interest rates, this plus what happened in the United States led the economy to a slowdown in growth, and for that year growth was $3.3 \%$, the following year 2009 was where the impact of what happened in the United States was felt the most since growth was $1.2 \%$. Although growth for 2009 was not negative, after the 1999 crisis it was the smallest expansion in the economy in the reference period.

Regarding the subprime crisis, Banco de la República (2009) affirms that several factors caused a slowdown in economic activity in our country, but the one that was increased by the decrease in remittances sent from abroad to Colombia, accompanied by a decrease in exports as a result of lower external demand for our products, determining factors in the crisis in the real sector of the economy. For his part, Uribe (2011) maintains that the role of financial institutions is of vital importance and that the lack of transparency affects the wellbeing of investors and, in general, the macroeconomic stability of a nation.

\section{Importance of Financial literacy in SMEs}

Álvarez and Abreu (2008) point out that for a small or medium-sized company, financial strategies are of vital importance when it comes to obtaining good economic results and avoiding unfavorable results; in the same way, it is also essential to cover financially in the face of constant fluctuations in the currency, the instability of interest rates and the constant movements of the stock markets, in order to be able to leverage strong financial movements. This is in order to minimize the impact that SMEs may suffer from in emerging countries and especially in the Colombian economy. To say that a company is a micro, small or medium company in Colombia according to Law 590 of 2000 , one must consider the number of employees and the total value of their assets. 
Table 2: Classification of companies according to their size according to law 590 of 2000

\begin{tabular}{|l|l|}
\hline & Employees \\
\hline Micro & $\mathrm{E}<10$ \\
\hline Small & $11<\mathrm{E}<50$ \\
\hline Medium & $51<\mathrm{E}<200$ \\
\hline
\end{tabular}

According to Banco de la República in September 2009, the international financial crisis of 2008 had an impact on companies and their finances since, given the scarcity of resources in international markets, there was a recomposition of the debt, which generated higher interest payments and a lower profitability that went from $6.9 \%$ to $6.7 \%$. This report quotes ANDI, and says that some companies endured this situation with financial and administrative education strategies such as optimizing their costs, seeking new marketing strategies, innovations and the development of new products, among others.

Regarding the optimization of costs, Gómez (2011) presents the case of children's clothing in Bucaramanga, which are small companies and concludes that most of these companies did not have a modern system to take their costs into account, but they applied some strategies to minimize them, such as taking advantage of the experience of each worker that is obtained after a certain period of time in which they have worked in that work and taking advantage of technological advances to increase production.

The strategies for cost control and minimization are mainly focused on the good performance of human resources through the experience curve, increases in production levels and the technology applied to processes. Most of these organizations lack cutting-edge tools, although they have specialized machines. One of the strengths is that reflected in the knowledge of human resources expressed in high-quality artisan production, with innovative designs, elements that become added value to compete in the market with differentiated products.

In an empirical study, Restrepo (2005) observes that, despite the modernization and the transition to technology carried out by SMEs, they are not yet within their priorities and sometimes they lack resources in terms of information systems, mining data, commercial creativity.

Whatever the strategy used by companies, any positive or negative result affects their finances and economic results, so financial literacy is very important for the proper management of resources. According to García, Grifoni, López and Mejía (2013), financial literacy is a tool that in times of economic growth can improve finances if the financial markets are used when they have favorable conditions, in the opposite of crisis it is also possible to cushion the effects of the fall in production and the worst conditions in the financial markets.

However, in the Colombian business reality, what is observed is a lack of business financial literacy in SMEs, in the special report on Financial Stability published in May 2019 by Banco de la República, it is evident that the majority of companies in Colombia are is financed through the acquisition of bank credit (in Colombia and abroad), with Financial Leasing and Factoring, through credit with the reinvestment providers of the profits and / or through the own resources that are not derived from the profits. Among the companies that use national bank credit as the first option, many use microcredits as a form of financing, which presents problems of over-indebtedness and the portfolio of the entities that provide this service has deteriorated and in general the perceived economic prospects are not the same.

Currently, given the recognition that financial literacy has been given as a requirement for SMEs to have better results, programs have been implemented that seek to train companies in these topics, free of 
charge, trainings by banks and entities of the financial system, through booklets and virtual programs. Asobancaria (2017) states that financial literacy is very important for SMEs, since among the reasons for bankruptcy of this type of companies is the low level of financial matters that SMEs have.

Regarding the issue of financial crises and the stability and survival of SMEs, Medina (2015) points out that financial crises are often the result of a lack of solid knowledge regarding the services and products that different financial institutions offer to investors and clients, being financial literacy a tool to improve decision making. Likewise, the author points out that the lack of education in SMEs causes them to have to leverage through their own resources or other non-formal sources, which increases the degree of financial exclusion for these companies. For his part, Soto (2016) points out that financial literacy allows companies to be able to face financial crises and to know the risks they may be exposed to.

\section{Conclusions}

The crises studied here had strong effects on the economic dynamics of Colombia and the Latin American countries that were taken as a reference, given the influence that financial markets have on real activity, not only of their countries but of those with which it has commercial and financial relationships. The documentary review shows that, in Colombia after the fall and slowdown in production measured through the percentage change in GDP, after the financial crises of 97 and 2008 respectively, it brought other consequences at the macroeconomic level such as inflation, indebtedness, instability in the financial system, volatility in the exchange rate, among others, which internally accentuated the effects of the crisis.

It was also evident that the crises, apart from affecting the Colombian economy as a whole, negatively impacted the most vulnerable companies, which are the smallest, since they have limited information and of the people who manage the business and make the financial decisions of the company do not have a sufficient level of financial literacy.

This reflects on how limited financial literacy can lead to the effects of external factors such as international financial crises, affecting smaller companies in the country compared to others with technical tools at their fingertips. Taking into account the importance of financial literacy, governments and private entities have chosen to offer free programs, so that people of all ages and educational levels can learn some of the main concepts contained in this term, however, it is evident that At the national and international level so far they are of little scope and that there is a need to formulate more programs that are focused on SMEs and that are tailored to their needs since most of these are oriented to the issue of personal finances that are the foundation of financial culture.

\section{References}

- Álvarez, M. y Abreu, J. L. (2008). Estrategias financieras en la pequeña y mediana empresa. Revista Daena (International Journal of Good Conscience), 3(2). Disponible en: http://www.spentamexico.org/v3n2/3(2)\%2065-104.pdf

- Asociación Bancaria y de Entidades Financieras de Colombia (ASOBANCARIA). (2017). La educación financiera como motor de las MISMES en Colombia. Semana Económica 2017, 1094, 1-10. Disponible en: https://www.asobancaria.com/wpcontent/uploads/2018/02/1094.pdf

- Banco de la República, (1999). Informe de Inflación. Diciembre de 1999. Disponible en: http://www.banrep.gov.co/sites/defa ult/files/publicaciones/archivos/dicie mbre 21.pdf

- $\quad$ Banco de la República, (2009). Reporte de Estabilidad Financiera. Septiembre de 2009. Disponible en: http://www.banrep.gov.co/sites/defa ult/files/publicaciones/archivos/septi embre 24.pdf 
- $\quad$ Banco de la República, (2019). Reporte de Estabilidad Financiera. Mayo de 2019. Disponible en: http://www.banrep.gov.co/es/reporte -estabilidad-financiera-primersemestre-2019

- Banco Interamericano de Desarrollo (BID), (2002). Guía operativa para programas de competitividad para la pequeña y mediana empresa. Serie de buenas prácticas del departamento de desarrollo sostenible, 1-31. Disponible en:

http://www.redmicrofinanzas.cl/inde x files/33321guiaopyme.pdf

- Belda, A. N. (2008). La crisis financiera de Estados Unidos. Boletín económico de ICE. Disponible en: http://www.revistasice.com/cachepdf $\angle B I C E 2953$ 19-

30 D0D7CC90785D87A456DC9AD37 FA57C63.pdf

- Chomsky, N. (2000). Plan Colombia. Revista Innovar Journal Revista de Ciencias Administrativas y Sociales, 1(16), 9-26. Recuperado de https://revistas.unal.edu.co/index.php Linnovar/article/view/24370/24974

- Chor, D. \& Manova, K. (2012). Off the cliff and back? Credit conditions and international trade during the global financial crisis. Journal of international economics, 87(1), 117-133. Disponible en:

http://www.sciencedirect.com/science /article/pii/S0022199611000493

- Clavijo, S. (2000). Las multilaterales y la crisis asiática (1997-2000): La Visión Desde un País Usuario (Colombia) (No. 003119). Banco de la República. Disponible en: http://www.banrep.gov.co/docum/ftp /borra142.pdf

- Comisión Económica para América Latina y el Caribe CEPAL, (1998). Impactos de la Crisis Asiática en América Latina. Disponible en: http://repositorio.cepal.org/bitstream /handle/11362/14951/S9800032_es.p df?sequence $=1$

- Cuasquer, H. y Maldonado, R. (2011). Microfinanzas y microcrédito en Latinoamérica. Boletín, 57(4), 179-193. Disponible
http://www.cemla.org/PDF/discusion LDDI-2011-03-02.pdf

- Erdmann, W., Schulz, N., Richter, M., y Rodriguez, E. F. (2008). Efectos del fenómeno del niño 1997-1998 en la vegetación del desierto de Sechura, Región Paita hasta el año 2008. Arnaldoa, 15(1), 63-86. Disponible en: http://www.archiv.geographie.unierlangen.de/wp-

content/uploads/08_erdmann effectsE INino 090309.pdf

- Esquivel, G. y Larraín, F. (1999). América Latina frente a la crisis asiática. Estudios Públicos, 73, 5-30. Disponible en:

https://www.cepchile.cl/cep/site/arti c/20160303/asocfile/2016030318414 5/rev73 esquivel-larrain.pdf

- Ferguson, C. (2010). Inside Job. Documental

- García, N., Grifoni, A., López, J. y Mejía, D. (2013). $N^{\circ} 12$. La educación financiera en América Latina y el Caribe. Situación actual y perspectivas. Recuperado de https://www.oecd.org/daf/fin/financi aleducation/OECD_CAF_Financial Educa tion Latin AmericaES.pdf

- Gómez, O. (2011). Los costos y procesos de producción, opción estratégica de productividad y competitividad en la industria de confecciones infantiles de Bucaramanga. Revista EAN, (70), 167$180 . \quad$ Disponible en: http://www.scielo.org.co/pdf/ean/n7 0/n70a14.pdf

- Guirao, J. A., Olmedo, A. y Ferrer, E. (2008). El artículo de revisión. Revista iberoamericana de enfermería comunitaria, 1(1), 1-25. Disponible en: https://www.uv.es/joguigo/valencia/ Recerca files/el articulo de revision.p $\underline{\mathrm{df}}$

- Johnson, S., Boone, P., Breach, A. \& Friedman, E. (2000). Corporate governance in the asian financial crisis. Journal of financial Economics, 58(1), 141-186. Disponible en: http://www.sciencedirect.com/science Larticle/pii/S0304405X00000696

- Larraín, F. y Sachs, J. (2002). Macroeconomía en la economía global. Buenos Aires, Argentina, México. Segunda edición. 
- Machinea, J. L. (2009). La crisis financiera internacional: su naturaleza y los desafíos de política económica. Revista Cepal. Disponible en: https://doi.org/10.18356/aa334828es

- $\quad$ Marcel, C. y Tapia, T. (2010). Efectos de la crisis financiera sobre las pensiones en América Latina (No. IDB-WP-152). IDB Working Paper Series. Disponible en:

https://www.econstor.eu/bitstream/1 0419/115385/1/IDB-WP-152.pdf

- Medina, S. A. (2015). Educación financiera, apoyo a SMEs para el financiamiento de sus Negocios. Disponible en: https://repository.cesa.edu.co/bitstrea m/handle/10726/843/TMF378.pdf?se quence $=2$ \&isAllowed $=y$

- Mockus, A. (2016). Entrevista sobre educación inclusiva: una perspectiva de Antanas Mockus sobre la inversión político-estatal en Colombia para garantizar el desarrollo socio económico (Interview on inclusive education: an Antanas Mockus perspective on political-state). Inclusión \& Desarrollo, 3(2), 14-16. Disponible en: https://doi.org/10.26620/uniminuto.i nclusion.3.2.2016.14-16

- Ocampo, J. A. (2009). Impactos de la crisis financiera mundial sobre América Latina. Revista Cepal. Disponible en: http://repositorio.cepal.org/bitstream /handle/11362/11269/097009032 es .pdf?sequence $=1$ \&amp;isAllowed $=\mathrm{y}$

- Palomo, R. y Sanchís, J. (2010). Efectos de las fusiones sobre la concentración y la eficiencia bancaria: el caso de las Cajas Rurales y los retos de la crisis financiera. Spanish Journal of Finance and Accounting/Revista Española de Financiación y Contabilidad, 39(146), 289-319. Disponible en: https://dialnet.unirioja.es/servlet/arti culo?codigo $=3248258$

- Restrepo, M. L. (2005). El mercadeo relacional observado en la práctica empresarial de la SMEs.Bogota, Colombia.

- Samuelson, P. (1967). Curso de Economía Moderna. Madrid, España.15 edición.

- $\quad$ Samuelson, P., y Nordhaus, W. (2010). Economía con aplicaciones a Latinoamérica. C. D. México, México. 19 edición.

- Soto, M. (2016). Microcréditos y educación financiera como factores clave del crecimiento económico en Colombia. Disponible en: https://repository.unimilitar.edu.co/bi tstream/handle/10654/15508/SotoPa terninaMariaElica2016.pdf.pdf?sequen ce=1\&isAllowed $=y$

- Titelman, D., Pérez, E. y Pineda, R. (2009). ¿Cómo algo tan pequeño terminó siendo algo tan grande?: Crisis financiera, mecanismos de contagio y efectos en América Latina. Revista Cepal. Disponible en: http://repositorio.cepal.org/bitstream /handle/11362/11293/098007034 es .pdf?sequence $=1$ \&isAllowed $=y$

- Uribe, J. D. (2011). Lecciones de la crisis financiera de 2008: cómo la infraestructura financiera puede mitigar la fragilidad sistémica. Revista del Banco de la República, 84(1004). Disponible en: http://www.banrep.gov.co/sites/defa ult/files/publicaciones/archivos/rbr_n ota 1004.pdf 